International Journal of Environment, Agriculture and Biotechnology
Vol-6, Issue-5; Sep-Oct, 2021
Journal Home Page Available: $\underline{\text { https://ijeab.com/ }}$
Journal DOI: $10.22161 /$ ijeab

\title{
In-Vitro Efficacy of Commercial Fungicides against Bipolaris Sorokiniana: Induced Spot Blotch Disease of Wheat
}

\author{
Sanskriti Acharya
}

Purbanchal University, Himalayan College of Agricultural Sciences and Technology, Nepal

Received: 1 Sep 2021; Received in revised form: 16 Oct 2021; Accepted: 25 Oct 2021; Available online: 31 Oct 2021 (C)2021 The Author(s). Published by Infogain Publication. This is an open access article under the CC BY license (https://creativecommons.org/licenses/by/4.0/).

\begin{abstract}
Spot blotch caused by Bipolaris sorokiniana is an important disease of wheat. A laboratory experiment was conducted at Plant Pathology Division, Nepal Agriculture Research Council, Khumaltar, Nepal to evaluate the efficacy of commercially available fungicides viz, Saaf ( Carbendazim 12\%+ Mancozeb63\%), Sectin (Fenamidone 10\%+ Mancozeb 50\%), Angel (Metalaxyl 8\%+ Mancozeb 64\%), Diathane M-45 (Mancozeb 75\%), G-MIL( Cymoxanil 8\%+ Mancozeb 64\%) tested in two different concentration i.e. 50ppm and 100 ppm except Curex (Copper oxychloride 50\%) tested in the concentration of 100ppm and 200ppm and Tilt (propiconazole 25\%) tested in 15ppm and 30 ppm concentration with a control test by employing poisoned food technique against spot blotch pathogen of wheat Bipolaris sorokiniana. The experiment was laid out in Completely Randomized Design (CRD). The result revealed that all concentrations of different fungicides successfully inhibited the radial mycelial growth of the pathogen under in vitro condition. Based on the measurement of fungal radial growth, fungicide Tilt of 30ppm and 15 ppm concentration were the most effective followed by Sectin 100ppm, Diathane M-45 100ppm, Angel 100 ppm and Saaf 100ppm. G-MIL 50 ppm in poisoned food technique was the least effective. Use of safer and economical chemical fungicides can provide an effective and long-term solution against plant diseases in agricultural farming.
\end{abstract}

Keywords - Spot blotch, Tilt, Trichoderma, efficacy, fungicides, pathogen.

\section{INTRODUCTION}

After rice and maize, wheat (Triticum aestivum) is Nepal's third most significant cereal crop. Wheat is produced from the Terai to the high alpine regions, and wheat consumption is on the rise. However, the yield per unit is much lower than anticipated. The disparity between the maximum observed yield and the national average yield, as well as the declining yield trend, necessitate immediate research. The low yield is due to a number of factors, including the scarcity of improved varieties, the occurrence of various wheat diseases, a lack of reliable irrigation, inclement weather, a lack of improved technology, and biotic and abiotic stress factors, all of which result in significant yield losses each year (Joshi et al., 2007). Fungal diseases in wheat cultivation are more important among biotic stress factors because they produce a significant drop in yield as well as deterioration in grain quality. In the humid subtropics of South Asia, where the irrigated rice-wheat rotation covers more than 12 million ha, there is growing evidence that stress conditions are increasing the severity of foliar diseases (Dubin et al., 1994) because rice serves as a host for the spot blotch fungi and rice stubble plays its role as a substrate for the fungi after rice harvest (Saari, 1998). Therefore, the fungal pathogen, Bipolaris sorokiniana (Sacc.) Shoemaker (teleomorph Cochliobolus sativus) induced spot blotch disease of wheat has emerged as one of the prime diseases for profitable wheat production in different zones of Nepal. Spot Blotch is caused by Bipolaris sorokiniana in Mega Environment 5A (ME5A), characterized by high temperature (coolest month greater than $17^{\circ} \mathrm{C}$ ) and high relative humidity (RH) (Dubin et al., 1991; Rajaram et al., 1993). It is a seed borne fungal. Spot blotch (oval to round brown blotch encircled by yellow halo) is the pathogen's principal symptom. The pathogen's continuing growth and 
development results in increasing leaf and spike damage, leading in yield loss. The disease occurs every year in Nepal in moderate to severe form (Duveiller et al., 2005). Bipolaris sorokiniana was also identified as a main contributing factor in a study undertaken in Nepal in 1996 to investigate and identity the national issue of "low germination in wheat' (Shrestha et al., 1997). The losses due to spot blotch in warm regions of Nepal ranged from $23-40 \%$ depending on the genotypes and other environmental factors (Tripathi et al., 2005; Sharma et al., 2006).

To lessen the losses caused by the disease, a range of syste mic fungicides with various modes of action and targets ha ve been developed (Pasquer et al., 2005). However, in vitro evaluation against Bipolaris sorokiniana are barely sufficient and even accurate information on determining efficacy, sensitivity of different fungicides with minimum inhibitory concentrations have yet to be defined against Bipolaris sorokiniana (Iqbal, 2010). It is important to examine the effect of different concentration of fungicides commonly available in market to control this disease.

\section{MATERIALS AND METHOD}

Subculture of pathogen was made by transferring cells from a previous year pure culture to petri-dishes containing fresh growth medium (Potato Dextrose Agar) and incubating at $25^{\circ} \mathrm{C}$ for 6 days to prepare the test pathogen (Bipolaris sorokiniana). The pure culture was isolated from infected leaves of wheat crop showing characteristic blight symptoms in the research field of Plant Pathology Division under Nepal Agriculture Research Council.

Seven fungicides with two different concentrations were evaluated for their efficacy to inhibit the mycelium growth of $B$. sorokiniana under in vitro condition following poisoned food technique. Five fungicides (Saaf, Sectin, Angel, Diathane M-45, G-MIL) with two concentration viz., 50 and $100 \mathrm{ppm}$, one fungicide ( Curex) with two different concentration viz., 100 and 200 ppm and one fungicide (Tilt) with two different concentration viz., 15 and $30 \mathrm{ppm}$ were evaluated. Concentration (PPM) of the fungicide was calculated based on active ingredients (a.i.) of the pesticide provided by the company on each packet. Stock solution of each fungicide was prepared in distilled water and incorporated into Potato dextrose agar medium and mixed thoroughly before autoclaving. After autoclaving the medium was poured aseptically in sterilized petri-plates of $9 \mathrm{~cm}$ size under laminar air flow and allowed to cool. Five mm mycelial circular discs of pathogen excised with sterile cork borer from a seven days old culture of test pathogen was placed at the centre of each petri-plate and incubated at $25^{\circ} \mathrm{C}$. PDA with water or without chemical served as control. The experiment was arranged in complete randomized design (CRD) and there were four replications for each (15) treatments. The plates were incubated at $25{ }^{\circ} \mathrm{C}$ inside $\mathrm{BOD}$ incubator. Measurement of the colony diameter of pathogens was taken after 48 hours for 10 days ( i.e $2^{\text {nd }}, 4^{\text {th }}, 6^{\text {th }}, 8^{\text {th }}$ day and $10^{\text {th }}$ day) after inoculation with the help of vernier caliper. Percent growth inhibition of the pathogen was calculated by using the following formula of Vincent (1947).

$\mathrm{I} \%=\frac{C-T}{C} \times 100$

Where,

$\mathrm{I}=$ inhibition percentage

$\mathrm{C}=$ Colony diameter in control and $\mathrm{T}=$ Colony diameter in treatment

The data collection started from 48 hours after poisoned food technique i.e. 8 th to $18^{\text {th }}$ March 2021 . The data were recorded by measuring the growth of the test pathogen after each 24 hours by using Vernier caliper in $\mathrm{mm}$. The data obtained from the experiment were analyzed using the software Gen Stat for the analysis of variance (ANOVA) to test the significance of treatments effect on mycelial growth of Bipolaris sorokiniana. Means of significant treatments at 5\% level of significance were compared following Duncan's Multiple Range Test (DMRT) and Microsoft Excels.

Table 1 Commercial agrochemicals (treatments) used in the study

\begin{tabular}{|l|l|l|l|l|l|}
\hline SN & Commercial Name & Common Name & $\begin{array}{l}\text { Active } \\
\text { Ingredients } \\
(\mathbf{a . i .})\end{array}$ & $\begin{array}{l}\mathbf{5 0} \\
\mathbf{p p m} \\
(\mathbf{m g})\end{array}$ & $\begin{array}{l}\mathbf{1 0 0} \\
\mathbf{p p m} \\
(\mathbf{m g})\end{array}$ \\
\hline 1. & Saaf & Carbendazim 12\% +Mancozeb 63\% WP & 75 & 6.67 & 13.33 \\
\hline 2. & Sectin & Fenamidone 10\%+ Mancozeb 50\% EC & 60 & 8.33 & 16.67 \\
\hline 3. & Angel & Metalaxyl 8\% + Mancozeb 64\% WP & 72 & 6.94 & 13.89 \\
\hline 4. & Diathane M-45 & Mancozeb 75\% WP & 75 & 6.67 & 13.33 \\
\hline 5. & G-MIL & Cymoxanil 8\% + Mancozeb 64\% WP & 72 & 6.94 & 13.89 \\
\hline
\end{tabular}




\begin{tabular}{|l|l|l|l|l|l|}
\hline SN & $\begin{array}{l}\text { Commercial } \\
\text { Name }\end{array}$ & Common Name & $\begin{array}{l}\text { Active } \\
\text { Ingredients } \\
\text { (a.i. })\end{array}$ & $\begin{array}{l}\mathbf{1 5} \\
\text { Ppm }\end{array}$ & $\begin{array}{l}\text { 30 } \\
\text { Ppm }\end{array}$ \\
\hline 6. & Tilt & Propiconazole 25\% EC & 25 & 6 & 12 \\
\hline SN & Commercial Name & Common Name & $\begin{array}{l}\text { Active } \\
\text { Ingredients } \\
\text { (a.i. })\end{array}$ & $\begin{array}{l}\mathbf{1 0 0} \\
\text { Ppm }\end{array}$ & $\begin{array}{l}\mathbf{2 0 0} \\
\text { Ppm }\end{array}$ \\
\hline 7. & Curex & Copper oxychloride 50\% WP & 50 & 20 & 40 \\
\hline 8. & Control & Water (Distilled) & 0 & 0 & 0 \\
\hline
\end{tabular}

\section{RESULTS AND DISCUSSION}

3.1 Effect of commercial fungicides on the radial growth of mycelium of Bipolaris sorokiniana by poisoned food method

Chemical fungicides viz, Saaf ( Carbendazim 12\%+ Mancozeb63\%), Sectin (Fenamidone 10\%+ Mancozeb 50\%), Angel (Metalaxyl 8\%+ Mancozeb 64\%), Diathane M-45 (Mancozeb 75\%), G-MIL( Cymoxanil 8\%+ MAncozeb 64\%) were tested in two different concentration i.e. 50ppm and $100 \mathrm{ppm}$ except Curex (Copper oxychloride 50\%) which was tested in concentration of $100 \mathrm{ppm}$ and $200 \mathrm{ppm}$ and Tilt (propiconazole $25 \%$ ) tested in $15 \mathrm{ppm}$ and $30 \mathrm{ppm}$ concentration against Bipolaris sorokiniana. In the table below, data were transformed to standard unit $(\mathrm{cm})$ to avoid statistical complications during analysis and data were and rounded to hundredth decimal unit. From the result it was observed that poisoned food method showed all fungicides tested with different concentration inhibited the radial growth of Bipolaris sorokiniana as compared to untreated control.

Means with the different letters are significantly different at $5 \%$ level of significance using LSD. In (Table 2), different letters in a column signifies that the treatment means are significantly different with each other at P-value $<0.001$.

Table 2 Mean radial growth of mycelium of Bipolaris sorokiniana in presence of commercial fungicides

\begin{tabular}{|c|c|c|c|c|c|}
\hline \multirow[b]{2}{*}{ Fungicides } & \multicolumn{5}{|c|}{ Mean radial mycelial growth (cm) } \\
\hline & Day 2 & Day 4 & Day 6 & Day 8 & Day 10 \\
\hline Saaf 100ppm & $0.00^{\mathrm{g}}$ & $0.99^{\text {gh }}$ & $1.25^{\mathrm{f}}$ & $1.55^{\mathrm{f}}$ & $2.03^{\mathrm{hi}}$ \\
\hline Saaf 50ppm & $0.90^{\mathrm{d}}$ & $1.46^{\mathrm{d}}$ & $2.07^{\mathrm{cd}}$ & $2.75^{b c}$ & $3.37^{b c}$ \\
\hline Sectin 100ppm & $0.00^{g}$ & $0.00^{\mathrm{i}}$ & $0.74^{\mathrm{g}}$ & $0.88^{\mathrm{g}}$ & $1.06^{\mathrm{k}}$ \\
\hline Sectin 50ppm & $0.84^{\mathrm{de}}$ & $1.37^{\mathrm{de}}$ & $2.01^{\mathrm{cd}}$ & $2.34^{\mathrm{d}}$ & $2.600^{\text {ef }}$ \\
\hline Angel 100ppm & $0.63^{f}$ & $0.85^{\mathrm{h}}$ & $1.08^{\mathrm{f}}$ & $1.59^{\mathrm{f}}$ & $1.82^{\mathrm{ij}}$ \\
\hline Angel 50ppm & $0.86^{\mathrm{de}}$ & $1.45^{\mathrm{d}}$ & $2.10^{\mathrm{cd}}$ & $2.60^{\mathrm{c}}$ & $2.88^{\mathrm{de}}$ \\
\hline Diathane M-45 100ppm & $0.69^{\mathrm{f}}$ & $0.83^{\mathrm{h}}$ & $1.09^{\mathrm{f}}$ & $1.35^{\mathrm{f}}$ & $1.54^{\mathrm{j}}$ \\
\hline Diathane M-45 50ppm & $0.83^{\mathrm{de}}$ & $1.14^{\mathrm{fg}}$ & $1.73^{\mathrm{e}}$ & $2.05^{\mathrm{e}}$ & $2.44^{\mathrm{fg}}$ \\
\hline G-MIL 100ppm & $0.74^{\text {ef }}$ & $1.21^{\mathrm{ef}}$ & $1.94 \mathrm{de}$ & $2.67^{\mathrm{c}}$ & $3.20^{\mathrm{c}}$ \\
\hline G-MIL 50ppm & $0.88^{\mathrm{d}}$ & $1.49^{\mathrm{d}}$ & $2.25^{\mathrm{c}}$ & $2.99^{\mathrm{b}}$ & $3.63^{\mathrm{b}}$ \\
\hline Curex 200ppm & $1.52^{\mathrm{c}}$ & $1.93^{\mathrm{c}}$ & $1.95^{\mathrm{de}}$ & $2.18^{\mathrm{de}}$ & $2.24^{\mathrm{gh}}$ \\
\hline Curex 100ppm & $1.76^{\mathrm{b}}$ & $2.50^{\mathrm{b}}$ & $2.62^{b}$ & $2.81^{b c}$ & $3.08^{\mathrm{cd}}$ \\
\hline Tilt 30ppm & $0.00^{\mathrm{g}}$ & $0.00^{\mathrm{i}}$ & $0.00^{\mathrm{h}}$ & $0.00^{\mathrm{h}}$ & $0.00^{1}$ \\
\hline Tilt 15ppm & $0.00^{g}$ & $0.00^{\mathrm{i}}$ & $0.00^{\mathrm{h}}$ & $0.00^{\mathrm{h}}$ & $0.00^{1}$ \\
\hline Control & $2.15^{\mathrm{a}}$ & $4.77^{\mathrm{a}}$ & $6.92^{\mathrm{a}}$ & $8.36^{\mathrm{a}}$ & $9.00^{\mathrm{a}}$ \\
\hline Grand Mean & 0.78 & 1.33 & 1.85 & 2.27 & 2.59 \\
\hline LSD & 0.1137 & 0.1636 & 0.2299 & 0.243 & 0.2827 \\
\hline $\mathrm{CV}$ & $10.1 \%$ & $8.6 \%$ & $8.7 \%$ & $7.5 \%$ & $7.7 \%$ \\
\hline SEm & 0.0399 & 0.0574 & 0.0807 & 0.0853 & 0.0992 \\
\hline
\end{tabular}




\begin{tabular}{|l|l|l|l|l|l|}
\hline P-value & $<0.001$ & $<0.001$ & $<0.001$ & $<0.001$ & $<0.001$ \\
\hline Sedm & 0.0564 & 0.0812 & 0.1141 & 0.1206 & 0.1402 \\
\hline
\end{tabular}

CV: Coefficient of variation, LSD: Least significant difference, Means followed by the same letter in a column are not significantly different by Duncan's Multiple Range Test at $5 \%$ level of significance, SEm ( \pm ) indicates standard error of the mean, cm is centimeters

Data of Day 10 shows that the pathogen covered the entire petri-plate of $9 \mathrm{~cm}$ in the control treatment. Tilt $15 \mathrm{ppm}$ and Tilt 30 ppm made lowest or no growth of the pathogen. The lowest mean radial growth was observed in the treatment Sectin $100 \mathrm{ppm}(1.06 \mathrm{~cm})$ being the most effective fungicide treatment after Tilt 15 and $30 \mathrm{ppm}$. The radial growth of the pathogen was highly influenced by Tilt (30 and 15ppm) and Sectin 100ppm. While significant treatments, G-MIL 100ppm $(3.2 \mathrm{~cm})$ and Curex $100 \mathrm{ppm}$

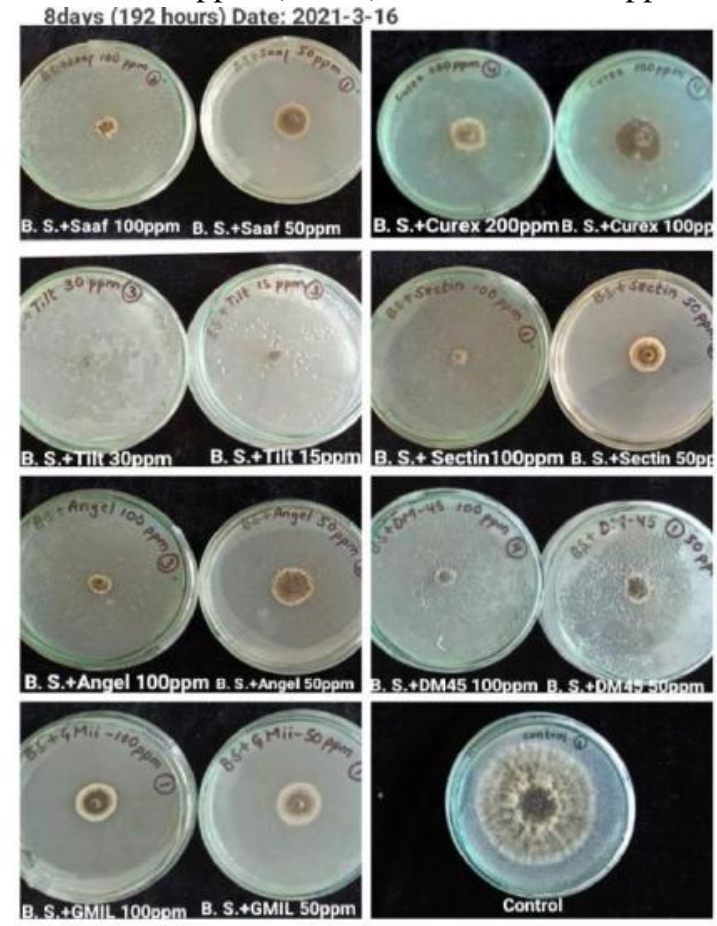

Radial mycelial growth of pathogen on Day 8
$(3.08 \mathrm{~cm})$ were least effective followed by significant treatments G-MIL50 ppm $(3.63 \mathrm{~cm})$, Saaf 50ppm $(3.37 \mathrm{~cm})$ as compared to other treatments. The results clearly demonstrated that the fungicide Tilt (Propiconazole 25\%) of both 30 and 15 ppm concentration followed by Sectin ( Fenamidone $10 \%$ + Mancozeb $50 \%$ ) of 100 ppm were individually effective against the pathogen by maximum inhibiting the mycelia growth in all days of data collection.

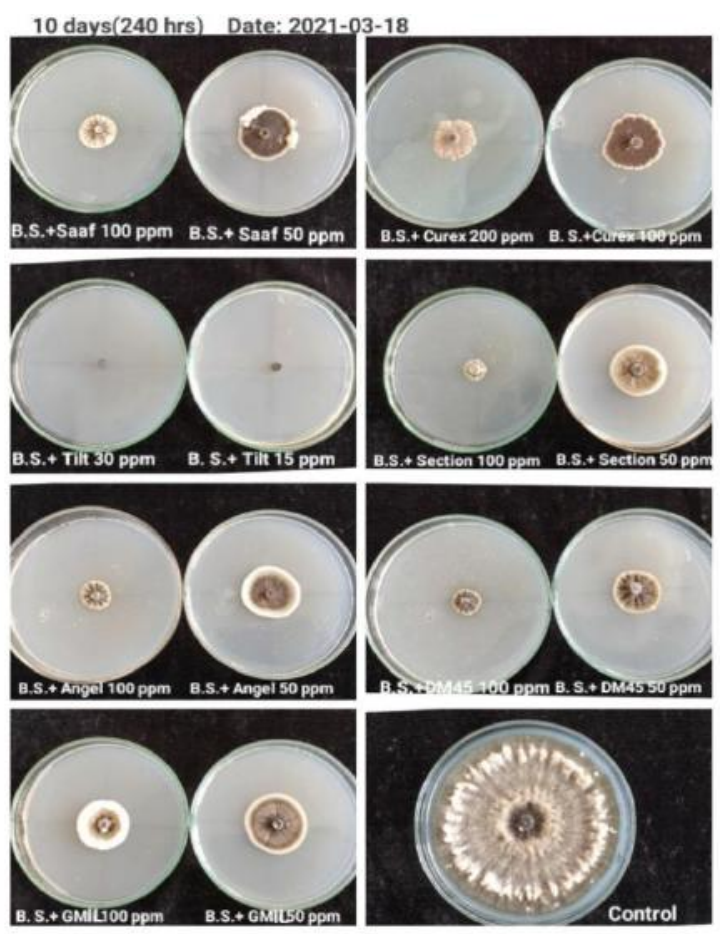

Radial mycelial growth of pathogen on Day 10

Table 3 Effect of commercial fungicides on the inhibition percentage of Bipolaris sorokiniana by poisoned food method

\begin{tabular}{|l|l|l|l|l|l|}
\hline \multirow{2}{*}{ Fungicides } & \multicolumn{5}{|c|}{ Mycelial growth inhibition (\%) } \\
\cline { 2 - 6 } & Day 2 & Day 4 & Day 6 & Day 7 & Day 10 \\
\hline Saaf 100ppm & 100.00 & 79.21 & 81.88 & 81.49 & 77.48 \\
\hline Saaf 50ppm & 58.24 & 69.24 & 70.04 & 67.12 & 62.50 \\
\hline Sectin 100ppm & 100.00 & 100.00 & 89.29 & 89.38 & 88.13 \\
\hline Sectin 50ppm & 60.90 & 71.29 & 70.93 & 72.06 & 71.11 \\
\hline Angel 100ppm & 70.77 & 82.08 & 84.33 & 80.90 & 79.72 \\
\hline Angel 50ppm & 60.09 & 69.66 & 69.63 & 68.85 & 68.00 \\
\hline Diathane M45 100ppm & 67.98 & 82.61 & 84.14 & 83.80 & 82.83 \\
\hline Diathane M45 50ppm & 61.60 & 76.05 & 75.05 & 75.49 & 72.91 \\
\hline G-MIL 100ppm & 65.55 & 74.60 & 72.01 & 68.01 & 64.44 \\
\hline G-MIL 50ppm & 59.16 & 68.73 & 67.44 & 64.22 & 59.67 \\
\hline
\end{tabular}




\begin{tabular}{|l|l|l|l|l|l|}
\hline Curex 200ppm & 29.58 & 59.56 & 71.77 & 73.84 & 75.11 \\
\hline Curex 100ppm & 18.21 & 47.61 & 62.21 & 66.38 & 65.78 \\
\hline Tilt 30ppm & 100.00 & 100.00 & 100.00 & 100.00 & 100.00 \\
\hline Tilt 15ppm & 100.00 & 100.00 & 100.00 & 100.00 & 100.00 \\
\hline Control & 0.00 & 0.00 & 0.00 & 0.00 & 0.00 \\
\hline
\end{tabular}

Irrespective of the low concentration, at the end of tenth day maximum inhibition of mycelial growth for the control of Bipolaris sorokinina was recorded in Tilt 30ppm (100\%) and Tilt 15ppm (100\%) which was significantly superior than other treatments followed by Sectin 100ppm (88.13\%) , Diathane M-45 100ppm $(82.83 \%)$, Angel 100ppm (79.72\%), Saaf 100ppm (77.48\%) and Curex 200ppm (75.10\%), Diathane M-45 $50 \mathrm{ppm}(72.90 \%)$ and Sectin 50ppm (71.10\%). The mycelial growth inhibition percentage ranged between 59.6 to $100 \%$ on tenth day of poisoned food experiment. The inhibitory effect of G-MIL50 ppm was the lowest i.e. $59.6 \%$. Looking at the percentage inhibition between same fungicides of different concentrations, the results revealed that inhibition percentages increased with the increase in concentration of fungicides. Most of the reports also concluded increase in concentration to be directly proportional to the increase in inhibition potential (Maitlo et al., 2014; Rafique et al., 2016). Among the fungicides, Tilt (Propiconazole 25\%) in almost all days of data collection was found to be significantly superior showing highest mycelial growth inhibition throughout the whole experiment.

Complete inhibition of radial mycelial growth and sporulation of Bipolaris sorokiniana was found with Tilt (Propiconazole), so it may be effective to completely control the pathogenic activity of Bipolaris sorokiniana. The result agrees with the results of various previous workers. Chattopadhyay et al., (2013) found out that Tricyclazole inhibited the melanin production and reduced the sporulation, spore size and number of septa in conidia of Bipolaris sorokiniana under in vitro condition. Triazole fungicides (e.g., propiconazole and tebuconazole) inhibit the synthesis of sterols, which are building blocks of the membranes of fungal cells. Response of Bipolaris sorokiniana on media containing fungicide of Triazole group (e.g.- Tebuconazole and Propinazole) reduced the growth of fungus successfully (Pannu et al., 2006; Sooväli and Koppel, 2009; Yamaguchi et al., 2010; Acharya et al., 2011; Rahman et al., 2013). Singh and Gupta (2000) studied the bioassay of fungicides against Dreschlera sativus causing leaf blight of wheat and the result recordes tilt to be the most effective fungicide in inhibiting the mycelial growth.
Diathane M-45 (Mancozeb) 100ppm (82.83\%) also successfully inhibited the mycelial growth. Giri et al. (2001) also demonstrated effectiveness of mancozeb $(90.5 \%)$ to control infection of seeds caused by Bipolaris sorokiniana. Mancozeb, belonging to the dithiocarbamate family, disrupt the metabolism of fungi by inhibiting either glucose oxidation, or nucleic acid synthesis, or by degradation of fatty acids (Angdembe et al., 2019). Mancozeb has direct effect upon the core biochemical processes within the fungus which results in inhibition of spore germination (Wong and Wilcox, 2001). Variation in the inhibition percentage of Bipolaris sorokiniana at different concentrations of mancozeb was reported in different experiments. There was higher $(82.83 \%)$ percent inhibition at $100 \mathrm{ppm}$ in our experiment whereas only 70 percent inhibition even at higher concentration of 400 ppm (Hasan et al., 2012) and 34 percent inhibition at 300 ppm (Samia et al., 2015) are also reported. These differences in inhibition rates may be due to different strains of Bipolaris sorokiniana and different quality of mancozeb used in these experiments. Sharma (2006) findings explored effectiveness of Mancozeb (Dithane M45) against rot of Coccinia indica caused by Bipolaris tetramera.

Mancozeb alone highly inhibited the growth of Bipolaris sorokiniana. However, it showed variations when used as combination fungicides. Mancozeb with Fenamidone inhibited the mycelial growth by $88.13 \%$ at $100 \mathrm{ppm}$. Mancozeb with carbendazim at $100 \mathrm{ppm}$ also showed better results i.e. $77.48 \%$ mycelial inhibition. Likewise Mancozeb with metalalxyl at 100 ppm showed $79.72 \%$ mycelial growth inhibition. But Mancozeb with Cymoxanil at 100 ppm (64.4\%) and 50 ppm (59.6\%) was lower as compared to other combinations.

It was reported that copper oxychloride showed $75.1 \%$ mycelial growth inhibition at $200 \mathrm{ppm}$ and $65.7 \%$ at $100 \mathrm{ppm}$. The mode-of-action of copper fungicides is the nonspecific denaturation of cellular proteins. It disrupts the function of proteins and enzymes after absorption and results in cell damage and membrane leakage (Husak, 2015). Samia et al. (2015) also reported 70-80\% mycelial growth inhibition in isolates of Bipolaris sorokiniana, collected from different region of Bangladesh, at 300 ppm concentration of copper oxychloride. 


\section{CONCLUSION}

Among the tested fungi-toxicants, Propiconazole (15 and $30 \mathrm{ppm}$ ) gave $100 \%$ mycelial inhibition of the test pathogen being the most effective fungicide followed by other single composition fungicides as well as combination fungicides viz., Fenamidone + Mancozeb 100ppm (88.13\%), Mancozeb (82.83\%), Metalaxyl + Mancozeb 100ppm (79.72\%), Carbendazim + Mancozeb 100ppm $(77.48 \%)$. The experiment showed variable effect of different fungicides of similar concentration. The effective treatments from the result of this study under in vitro conditions are only indicative and can be used to test for further trial under natural field condition (in pots or fields) for the confirmation of their efficacy against Bipolaris sorokiniana.

\section{ACKNOWLEDGEMENT}

Thanks to Plant Pathology Division, National Agricultural Research Council for providing opportunities; deepest appreciation for accommodating me to this large and renowned family.

\section{REFERENCES}

[1] Acharya, K., Dutta, A.K. and Pradhan, P., 2011. 'Bipolaris sorokiniana'(Sacc.) Shoem.: The most destructive wheat fungal pathogen in the warmer areas. Australian Journal of Crop Science, 5(9), 1064-1071.

[2] Angdembe, B., Dhakal. N., G.C. S., Pant, K.R.,\& Manandhar, H.K., 2019. In-vitro evaluation of commercially available fungicides against Bipolaris sorokiniana, the cause of spot blotch of Barley. Journal of Agriculture and Forestry University, 3, 105-111.

[3] Chattopadhyay, A. Kushwaha, C. Chand, R. and Srivastava, J.S., 2013. Differential mode of action of tricyclazole in vitro and in planta on Bipolaris sorokiniana causing spot blotch in barley. Indian Phytopathol, 66, 155-158.

[4] Dubin, H.J. and Bimb, H.P., 1994. Soil borne diseases of wheat in warmer areas of South Asia: An update. Wheat in Heat Stressed Environments: Irrigated, Dry Areas and Rice Wheat Farming Systems. Mexico, DF: UNDP/ARC/BARI/CIMMYT, 353-360.

[5] Dubin, H.J. and Ginkel, M.V., 1991. The status of wheat diseases and disease research in warmer areas. In Wheat for the nontraditional warm areas: a proceedings of the International Conference July 29-August 31990 Foz do Iguaçu, Brazil. (125-45). CIMMYT.

[6] Duveiller, E., Kandel, Y.R., Sharma, R.C. and Shrestha, S.M., 2005. Epidemiology of foliar blights (spot blotch and tan spot) of wheat in the plains bordering the Himalayas. Phytopathology, 95(3), 248-256.

[7] Giri, G.K., Gade, R.M. and Patil, C.U., 2001. Seed borne Bipolaris sorokiniana in wheat and its chemical control. Journal of Soils and Crops, 11(1), 109-112.
[8] Hasan, M.M., Ahmed, F., Islam, M.R. and Murad, K.F.I., 2012. In vitro effect of botanical extracts and fungicides against Bipolaris sorokiniana, causal agent of leaf blotch of barley. J. Agrofor. Environ, 6(1), 83-87.

[9] Husak, V.V., 2015. Copper and copper-containing pesticides: metabolism, toxicity and oxidative stress. Journal of Vasyl Stefanyk Precarpathian National University, (2, no. 1), 39-51.

[10] Iqbal, Z., Pervez, M.A., Ahmad, S.A.L.M.A.N., Iftikhar, Y., Yasin, M.U.H.A.M.M.A.D., Nawaz, A., Ghazanfar, M.U., Dasti, A.A. and Saleem, A., 2010. Determination of minimum inhibitory concentrations of fungicides against fungus Fusarium mangiferae. Pak. J. Bot, 42(5), 3525-3532.

[11] Joshi, A.K., Mishra, B., Chatrath, R., Ferrara, G.O. and Singh, R.P., 2007. Wheat improvement in India: present status, emerging challenges and future prospects. Euphytica, 157(3),431-446.

[12] Maitlo, S.A., Syed, R.N., Rustamani, M., Khuhro, R. and Lodhi, A., 2014. Comparative efficacy of different fungicides against fusarium wilt of chickpea (Cicer arietinum L.). Pakistan Journal of Botany, 46(6), 23052312.

[13] Pannu, P.P.S., Chahal, S.S., Sharma, V.K., Mandeep, K. and Bagga, P.S., 2006. Occurrence of brown leaf spot of rice in Punjab, its effect on grain yield and its control. Indian Phytopathology, 59(2), 190-193.

[14] Pasquer, F., Isidore, E., Zarn, J. and Keller, B., 2005. Specific patterns of changes in wheat gene expression after treatment with three antifungal compounds. Plant molecular biology, 57(5), 693-707.

[15] Rafique, K., Rauf, C.A., Naz, F. and Shabbir, G., 2016. Management of vascular wilt of lentil through host plant resistance, biological control agents and chemicals. Pakistan Journal of Botany, 48(5), 2085-2092.

[16] Rahman MM, Ali MS, Nahar A, Karim MM, Begum K, 2013. Efficacy of fungicides in controlling leaf blight of wheat. Int. J. Expt. Agric., 3, 1-3.

[17] Rajaram, S., Van Ginkel, M. and Fischer, R.A., 1993, July. CIMMYT's wheat breeding mega-environments (ME). In Proceedings of the 8th International wheat genetic symposium (19-24).

[18] Saari, E.E., 1998. Leaf blight disease and associated soilborne fungal pathogens of wheat in South and South East Asia. Helminthosporium Blights of wheat: spot blotch and tan spot, 37-51.

[19] Samia, T., Sultana, S., Adhikary, S.K. and Quddus, K.G., 2015. Effect of fungicides against Bipolaris sorokiniana isolates collected from different wheat growing regions of Bangladesh. Mycopath, 13(2), 81-88.

[20] Sharma, R.C. and Duveiller, E., 2006. Spot blotch continues to cause substantial grain yield reductions under resource-limited farming conditions. Journal of Phytopathology, 154(7-8), 482-488.

[21] Shrestha, K.K., R.D. Timila, B.N. Mahto and H.P. Bimb. 1997. Disease incidence and yield loss due to foliar blight of wheat in Nepal. Helminthosporium blight of wheat: spot blotch and tan spot. In: Proceedings of an International Workshop held at CIMMYT El Batan, Maxico. (Eds.): E. 
Duveiller, H.J. Dubin, J. Reeves and A. McNab. 9-14 February 1997. 67-72.

[22] Singh SN, Gupta AK., 2000. Bioassay of fungicides against Dreschlera sativus causing leaf blight of wheat, Indian Phyto pathological Society. 52nd Annual Meeting and National Symposium on Role of Resistance in Intensive Agriculture, Directorate of Wheat Research, Karnal, 25.

[23] Sooväli P, Koppel MP, 2009. Efficiency of fungicides tebuconazoe in barley varieties with different resistance level. Agric. Food Sci., 19, 34-42

[24] Tripathi, M.N. and Bhandari, C.M., 2005. Material parameters for thermoelectric performance. Pramana, 65(3), 469-479.

[25] Vincent, J. M. (1947). Distortion of fungal hyphæ in the presence of certain inhibitors. Nature 159(4051), 850-850

[26] Wong, F.P. and Wilcox, W.F., 2001. Comparative physical modes of action of azoxystrobin, mancozeb, and metalaxyl against Plasmopara viticola (grapevine downy mildew). Plant disease, 85(6), 649-656.

[27] Yamaguchi, K.I. and Mutsunobu, M., 2010. A simple selective medium for the primary isolation of Bipolaris, Drechslera and Exserohilum species. Bull. Minamikyushu Univ. 40A, 55, 58. 